\title{
Yield of Decoration Greenery Fraser Fir Christmas Trees
}

\author{
L. Eric Hinesley ${ }^{1}$ and Layne K. Snelling ${ }^{2}$ \\ Department of Horticultural Science, North Carolina State University, \\ Raleigh, NC 27695-7609
}

Additional index words. Abies fraseri, wreaths

\begin{abstract}
Fraser fir [Abies fraseri (Pursh) Poir.] Christmas trees up to $3.2 \mathrm{~m}$ in height were sampled from 18 well-managed plantations in western North Carolina to determine the yield of decoration greenery (wreaths, roping). Trees were not sidesheared in the year of harvest. The proportion of branch material suitable for decoration greenery decreased with increasing height and crown taper, but crown density had no effect. Mean annual yield of decoration greenery (establishment in the field, until reaching an average height of $3.2 \mathrm{~m} 10$ years later) was 1.9 to $2.3 \mathrm{~kg} /$ tree per year, respectively, for trees with medium or heavy crown density.
\end{abstract}

In the United States, decoration greenery has traditionally been collected from wild trees or forest plantations (Douglass, 1975; Williams, 1958). Fraser fir is an important Christmas tree species in North America. Most decoration greenery from Fraser fir is derived as a secondary product from intensively managed Christmas tree plantations. Healthy trees with poor form or appearance are used for greenery. Branches are also removed from the basal stem (handle), either before or during the year of harvest.

Demand for decoration greenery is increasing, and some producers might eventually encounter difficulty obtaining the quantity and quality of material they need. Dedicating a small area to production of greenery might solve this potential problem, but expected yields are unknown. Our objective was to determine yields of decoration greenery from Fraser fir Christmas trees.

Fraser fir Christmas trees $(\mathrm{n}=126)$ were collected in Nov. and Dec. 1989 and 1990 from 18 plantations and six counties in western North Carolina. Plantations were located on uplands at elevations between 800 and $1400 \mathrm{~m}$. Except for one county in southwestern North Carolina, the sample area was centered on latitudes $36^{\circ} 17^{\prime} \mathrm{N}$ and longitude $81^{\circ} 32^{\prime} \mathrm{W}$. Soils were derived from acid crys-

Received for publication 21 Mar. 1991. Accepted for publication 20 Sept. 1991. This research was funded by the North Carolina Agricultural Research Service, Raleigh, NC 27695-7643. Technical assistance by the following persons is gratefully acknowledged: Gene Brewer, Keith Eller, Jeff Hartsog, Johnny Hensley, Jeff Gwen, Danny Roten, and Jerry Washington. The following persons kindly contributed trees for this study: Waightstill Avery, Doug Clark, Howard Covington, Dale Duncan, Doug Francis, Mike Francis, Lewis Gaskins, Hal Gimlin, Max Higgins, Brian Hensley, Hal Johnson, Dale Shepherd, Bruner Sides, Clay and Mary Townsend, Dan Wilson, and Randy Wilson. The cost of publishing this paper was defrayed in part by the payment of page charges. Under postal regulations, this paper therefore must be hereby marked advertisement solely to indicate this fact.

'Professor.

${ }^{2}$ Research Technician. talline rock and micaceous rock, with representative series being Ashe, Chandler, Chester, Fannin, Hayesville, Porters, Tusquitee, and Watauga (Lee, 1955; U.S. Dept. Agr., 1973a, 1983).

This collective sample was representative of trees in normal production. Dimensions were as follows: commercial height (1.1 to $3.2 \mathrm{~m}$ ), stem diameter $15 \mathrm{~cm}$ above groundline (4.9 to $14.9 \mathrm{~cm})$, crown taper $(0.51$ to 1.05 ), years in the field (5 to 11). Fiftyseven trees had heavy crown density; 69 trees were medium density. Trees had been grown according to standard management practices, including annual sideshearing, annual fertilization, intensive weed control with herbicides and mowing, stocking levels near $100 \%$, and clipping of current leader length to $-0.3 \mathrm{~m}$ late in each growing season. To impart a natural appearance without visible cut branch ends, trees were not sidesheared in the year of sampling. Trees had not been basal pruned to form handles.

Before harvest, crown diameter of each tree (vertical projection) was measured in two directions (widest direction, and $90^{\circ}$ from widest), and crown density rated either as medium or heavy. In medium-density trees, portions of the stem were visible along the entire length of the tree, or there were visible openings between major whorls. Most of these trees were U.S. No. 2 grade, (U.S. Dept. Agr., 1973b). In heavy-density trees (mostly U.S. No. 1 or U.S. Premium), the stem was not usually visible, except in the upper crown, and whorls were not outwardly distinguishable.

Commercial height was the distance from the stem base to the apex of the cone of the taper applicable to the tree (U.S. Dept. Agr., 1973b). By definition, at least $75 \%$ of the branch ends touched or overlapped the line of the cone. By convention, trees were segregated into $0.3-\mathrm{m}$ height classes (e.g., 1.22 to $1.52 \mathrm{~m}, 1.53$ to $1.83 \mathrm{~m}$, etc.), with every tree in a particular class assigned a commercial height equal to the midpoint of the height class (e.g., $1.37 \mathrm{~m}, 1.67 \mathrm{~m}$, etc.). Crown taper was the ratio of average crown width : commercial height.
Following harvest, branches were cut from a $180^{\circ}$ sector of the crown, from the tree base to the stem apex, and weighed. On large trees, the sector was $60^{\circ}$ to $90^{\circ}$. Twigs suitable for wreaths were cut from this subsample and weighed. Remaining branches on the tree were also removed and weighed.

The ideal unit of greenery is a symmetrical, nonsheared; fully foliated section of 1and 2-year-old internodes ( $\approx 18$ to $30 \mathrm{~cm}$ long, basal twig diameter $17 \mathrm{~mm}$ ) with attached current-year side shoots. Where internodes are short, pieces can also contain sections of 3 -year-old internodes. The following types of branches were excluded: a) large, stout, in the upper two whorls; b) with thin or absent foliage; c) with excessively long current-year growth; d) with sparse or absent side branches, e) with diseased, discolored, or insect-damaged foliage; f) with visible pruning stubs; and g) asymmetrical. If a shoot is otherwise acceptable, it is common in c) to remove the long section of current-year growth from the primary axis and overlay the remainder with several smaller, more attractive twigs.

For each tree, the usable proportion (decoration greenery) was calculated as the usable weight in the subsample divided by the total subsample weight. Usable greenery in the tree was estimated as total branch weight $\times$ usable proportion (percent) in the subsample.

Stem diameter (two directions, $15 \mathrm{~cm}$ above groundline) was measured with calipers after branches were removed. Age (years in the

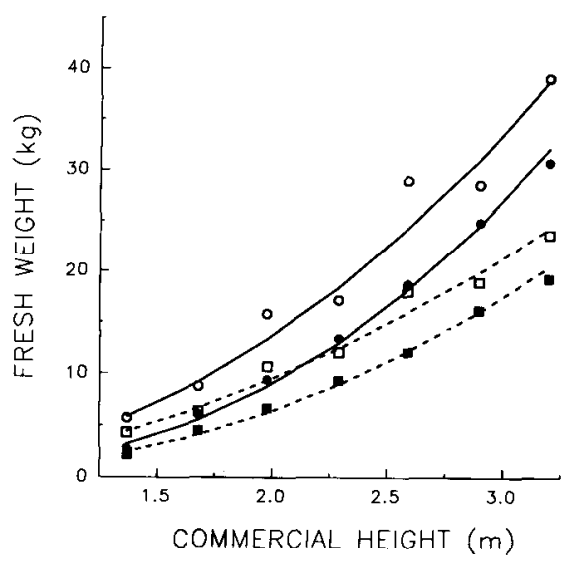

Fig. 1. Fresh weight $(\mathrm{kg})$ of branches and usable greenery from Fraser fir Christmas trees, by commercial height class and crown density. Legend: total branches, heavy crown density ( $O$ ); total branches, medium crown density ( ); usable greenery, heavy crown density ( $\square$ ); usable greenery, medium crown density ( $\boldsymbol{\square}$ ). Sample size: 57 heavy-density trees; 69 medium-density. The regression model for total fresh weight of branches (B) was as follows: $\operatorname{In}(\mathrm{B})=$ $-0.9599+2.7001[\ln (\mathrm{H})]+0.2562(\mathrm{D})+$ 2.1489(T), where $\mathrm{H}=$ commercial height class $(\mathrm{m})=$ midpoint of $0.3-\mathrm{m}$ increments (e.g., 1.37, 1.68 , etc. $), \mathrm{D}=$ crown density $(1=$ heavy; 0 $=$ medium $)$, and $\mathrm{T}=$ crown taper $(0.51 \leq \mathrm{T}$ $\leq 1.05) . R^{2}=0.92$. The model for fresh weight of usable greenery $(\mathrm{G})$ was as follows: $\operatorname{In}(\mathrm{G})=$ $-0.7418+2.4028[\ln (\mathrm{H})]+0.2705(\mathrm{D})+$ $1.56630 ; R^{2}=0.91$ 
field) was determined from whorl counts.

Regressions were developed with SAS (SAS Institute, 1985) to estimate total fresh weight of branches and usable greenery, using variables such as commercial height, stem diameter, crown density, and crown taper. A class variable was included for crown density: $0=$ medium, $1=$ heavy. Owing to the near impossibility of measuring lower stem diameter on a Fraser fir Christmas tree that has not been basal pruned, regressions in Fig. 1 include only height, crown density, and crown taper. $R^{2}$ values were about the same, with or without stem diameter in the model. Average bias in these regressions was $-1 \%$ (Snowdon, 1991).

Heavy-density trees had, on the average, $28 \%$ more weight of branches and foliage (fresh weight) than medium-density trees (Fig. 1). Although the proportion of above-ground plant material in branches was $71 \%$ to $75 \%$ across all height classes (data not shown), the proportion of branch mass constituting usable greenery decreased linearly from $76 \%$ in $1.4-\mathrm{m}$ trees to $62 \%$ in $3.2-\mathrm{m}$ trees.

Percent usable $=109.0-9.18(\mathrm{H})-$ 30.1(T), where $\mathrm{H}=$ commercial height $(\mathrm{m})$ and $\mathrm{T}=$ crown taper $\left(R^{2}=0.53\right)$. In this model, increasing crown taper had a significant, negative impact on the proportion of usable greenery, whereas crown density had little effect and was not included.

Sample trees with a mean commercial height of $1.4 \mathrm{~m}$ (mean age $=5.5$ years in the field) contained an average of 2.2 (medium density) to 4.4 (heavy density) $\mathrm{kg}$ of decoration greenery. Later, at a height of 3.2 $\mathrm{m}$ (average age $=9.8$ years in the field), they averaged 19.2 (medium) to 23.6 (heavy) $\mathrm{kg} / \mathrm{tree}$, respectively. This represented an average accumulation rate of 4.0 to $4.5 \mathrm{~kg} /$ tree per year during the last 4 or 5 years of the rotation. Allowing for an average initial fresh weight of $0.5 \mathrm{~kg}$ (L.E.H., unpublished), average yield over the entire rotation (establishment, until reaching a commercial height of $3.2 \mathrm{~m} 10$ years later) was $\approx 1.9$ (medium density) to 2.3 (heavy density) $\mathrm{kg} /$ tree per year. These results are similar to maximum yields of decoration greenery from well-managed, fertilized stands of noble fir (Abies proceru Rehd.) and Nordmann fir [A. nordmaniana (Stev.) Spach] on optimum sites in Denmark (Bang, 1979; Holstener-Jorgenson, 1972, 1982). Similarly, in a mixed forest stand of Douglas-fir [Pseudotsuga menziesii (Mirb.) France], noble fir and Pacific silver fir [Abies amabilis (Dougl.) Forbes] in the Pacific Northwest, reported bough yields were $2 \mathrm{~kg} /$ tree per year over 10 years (Murray and Crawford, 1981). A good quality, fresh Fraser fir wreath (0.30-m ring) contains $\approx 1.8 \mathrm{~kg}$ of greenery.

There were several reasons for using Christmas trees (not sheared in the year of harvest) rather than nonsheared, naturally grown trees. A Christmas tree plantation can be left unsheared for 1 or 2 years, and then be harvested for greenery. This offers the option of using trees as cut Christmas trees until late in the rotation. Nonsheared Fraser firs have less value as cut trees than sheared trees. Where the producer knew with certainty that trees would eventually be used only for greenery, not shearing the trees might be a viable option. Second, with increasing frequency, Christmas tree plantations are exchanging hands. Our estimates offer another tool for projecting present and future values, considering various use options and expected returns. Third, expenses increase dramatically with increasing tree size. We believe that few growers of Fraser fir would consider producing greenery via collections from the same trees over a long period, i.e., 15 or 20 years. Rather, they will prefer a system closely akin to Christmas tree culture and harvest while trees are small enough for easy handling and processing. This system is in limited operation. It is easier to conduct various management practices, e.g., fertilization, in sheared trees because they require less horizontal space, and crowns do not interlock. Notwithstanding, trees would not be sheared during the last 1 or 2 years before harvest to maximize the quantity of usable greenery.

Although we have no comparison of branch production on sheared and nonsheared trees, foliage mass in well-managed, fully stocked stands of 2.6-m Fraser fir Christmas trees (heavy density, 4400 trees/ha) is $\approx 17 \mathrm{t} \cdot \mathrm{ha}^{-1}$ (dry weight), which is similar to that in mature stands of Fraser fir-red spruce (Hinesley and Wright, 1989; Weaver and DeSelm, 1973). Accumulation of branches and foliage is possibly less in sheared trees, compared to nonsheared (Little, 1970), but trees produce considerable compensatory growth in buds and branches that remain after branch tips are removed (Powell, 1982). The compensatory growth goes into laterals of order $\geq 2$, which results in less coarse greenery that is better for wreaths. Tipping of branches, if conducted at the right time each growing season, and if not too heavy, affects the spatial distribution of foliage and branches (crown density) more than the actual quantity.

These data should be helpful in 1) projecting future yield of greenery from Christmas tree plantations, assuming no sideshearing during the year of harvest; 2) calculating conversion percentages for branches purchased or sold as greenery; and 3) determining the land area required to generate specified quantities of greenery per unit time.

\section{Literature Cited}

Bang, Carl. 1979. Various lopping methods and intensities for the production of decoration greenery of Abies procera (in Danish). Forstl. Forsøgsvæs. Dan. 37:1-22.

Douglass, B.S. 1975. Floral greenery: from Pacific Northwest forests. U.S. Forest Serv., Div. State and Private For., Portland, Ore.

Hinesley, L.E. and R.D. Wright. 1989. Biomass and nutrient accumulation in Fraser fir Christmass trees. HortScience 24:280-282.

Holstener-Jorgensen, H. 1972. Fertilization experiments in decoration green stands of Abies nobilis (in Danish). Forstl. Forsøgsvæs. Dan. $33: 77-82$

Holstener-Jorgensen, H. 1982. Fertilization experiments in stands of Abies nordmanniana used for greenery production (in Danish). Forstl. Forsøgsvæs. Dan. 38:221-237.

Lee, W.D. 1955. The soils of North Carolina: their formation, identification and use. North Carolina Agr. Expt. Sta. Tech. Bul. 115.

Little, C.H.A. 1970. Apical dominance in long shoots of white pine (Pinus strobes). Can. J. Bot. 48:239-253.

Murray, M.D. and P.D. Crawford. 1981. Timber and boughs; compatible crops from a noble fir plantation, p. 215-219. In: C.D. Oliver and R.M. Kenady (eds.). Proc. Biol. and Mgt. of True Fir in the Pacific Northwest Symp., 24-26 Feb. 1981, Univ. of Washington, College of Forest Resources, Contr. no. 45.

Powell, G.R. 1982. Shoot and bud development in balsam fir: implications for pruning of Christmas trees. For. Chronicle 58:172.

SAS Institute. 1985. SAS user's guide: statistics, version 5 edition. SAS Inst., Inc., Gary, N.C.

Snowdon, P. 1991. A ratio estimator for bias correction in logarithmic regressions. Can. J. For. Res. 21:720-724.

U.S. Department of Agriculture. 1973a. Soil survey of Alleghany County, North Carolina. U.S. Dept. Agr., Washington, D.C.

U.S. Department of Agriculture. 1973b. United States standards for grades of Christmas trees. U.S. Dept. Agr., Agr. Mktg. Serv., Washington, D.C.

U.S. Department of Agriculture. 1983. Soil survey of Ashe County, North Carolina. U.S. Dept. Agr., Washington, D.C.

Weaver, G.T. and H.R. DeSelm. 1973. Biomass distribution patterns in adjacent coniferous and deciduous forest ecosystems. IUFRO biomass studies. College Life Sci. and Agr., Univ. of Maine, Orono. p. 415-427.

Williams, W.K. 1958. Fraser fir as a Christmas tree. U.S. Dept. Agr., Forest Serv.-Ext. Serv. 